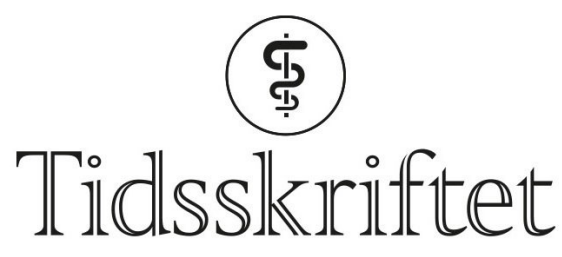

DEN NORSKE LEGEFORENING

\title{
Håpet om julefred
}

MINILEDER

ARE BREAN

Sjefredaktør

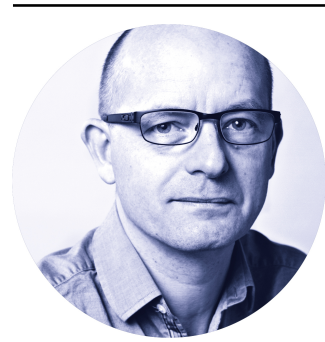

Idet vi går inn i årets julehøytid, er antallet flyktninger i verden rekordhøyt. Blant de mange flyktningkriser peker situasjonen i Syria seg fortsatt ut. Det er nå registrert over 5,2 millioner syrere på flukt i nabolandene. 1,7 millioner av disse er barn, ifølge FNs høykommissær for flyktninger. Tyrkia er det landet som har tatt imot flest.

Men Tyrkia har også sine egne menneskerettighetsutfordringer. Legen Serdar Küni fra grensebyen Cizre ble i mai $2017 \mathrm{~d} ø \mathrm{mt}$ til mer enn fire års fengsel, uten noen form for bevis, og deretter sluppet fri. Hans påståtte forbrytelse er at han skal ha gitt medisinsk hjelp til medlemmer av kurdiske styrker.

For om lag 2000 år siden levde og virket det en annen lokal lege i grenseområdet mellom Tyrkia og Syria. Han ble senere kjent som evangelisten Lukas og ga oss både juleevangeliet og fortellingen om den barmhjertige samaritan. Dagens syriske flyktninger kan trenge det håpet begge disse fortellingene inspirerer til. Og vi andre kan bli minnet om vår medmenneskelige plikt til å hjelpe.

Publisert: 12. desember 2017. Tidsskr Nor Legeforen. DOI:10.4045/tidsskr.17.23.01

(C) Tidsskrift for Den norske legeforening 2020. Lastet ned fra tidsskriftet.no 